\section{Britain wins bid to host ocean drilling office}

London. British marine geophysicists are rejoicing over the successful bid by the University of Wales, Cardiff, and the Natural Environment Research Council to be the first non-US host of the science planning office of the international ocean-drilling programme (ODP).

IMAGE UNAVAILABLE $\begin{gathered}\text { The Na- } \\ \text { tional Science }\end{gathered}$ FOR COPYRIGHT REASONS

Foundation, which runs the programme, provides just over half of its $£ 28$ million (US\$40 million) annual rest comes

from its six

\section{The JOIDES Resolution} other members, including four individual countries - Britain, France, Germany and Japan - a consortium of smaller European countries organised through the European Science Foundation and a joint membership of Canada and Australia (Russia has withdrawn because of financial difficulties).

The scientific content of the ODP programme, begun in 1985, is coordinated through a body known as the Joint Oceanographic Institutions Deep Earth Sampling (JOIDES). Subscriptions from members are used to pay for a converted oil explorations York. budget. The

ship, the JOIDES Resolution, based in Austin, Texas, under contract to JOI, Inc., a Washington-based organization.

The JOIDES planning office, which coordinates the programme's scientific agenda, coordinates the work of a number of committees. It has been based for successive two-year periods at a series of US universities; its home until the end of 1994 is the University of Washington in Seattle.

It was decided to locate the office outside the United States to encourage scientists from other countries to feel more involved in planning the scientific agenda. Cardiff won the contract, worth $£ 400,000$ (US\$600,000) for two years, against two other international bids.

A major factor behind JOIDES's decision to locate its planning office in Cardiff is the return of the JOIDES Resolution later this year from the North Pacific to the North Atlantic, where it carried out its first drilling in 1985. "People beat a path to your door to tell you what is going on", says Joe Cann, professor of earth sciences at the University of Leeds. "Having a pipeline of hot topics coming into Cardiff gives us a big scientific advantage in planning our own research." Projects planned for 1994-95 include investigations of the hydrothermal mounds on the mid-Atlantic ridge and a drilling programme on the Barbados ridge to look at fluid flow in ocean-bed sediments.

Two other ODP contracts are also open for bids. One is for a new computing system on the ship, and the other for the data storage - or "logging" - facilities now provided by the Lamont Doherty Observatory in New

David Dickson

\section{French AIDS team wins Faisal Prize}

London. Three French AIDS researchers and two physicists, one German and one from the United States, have received the 1993 King Faisal International Prize in medicine and physics respectively. The prize is also awarded annually for service to Islam, Islamic studies and Arabic literature, and each recipient receives $\$ 100,000$.

This year's medicine prize honours Luc Montagnier, Jean-Claude Chermann and Francoise Barre-Sinoussi for their work on identifying HIV and the way in which it damages the human immune system. Working together in the viral oncology unit of the Pasteur Institute in Paris, the three researchers isolated in 1983 what they then described as the "lymphadenopathyassociated virus" (LAV), subsequently shown to be the virus responsible for AIDS.
Montagnier has recently set up a new body known as the World Foundation for Research and Prevention of AIDS (see Nature 361, 287; 1993). Barre-Sinoussi is head of the Retrovirus Biology Laboratory of the National Institute of Health and Medical Research (INSERM), based at the Pasteur Institute. Chermann is now director of INSERM's Laboratory of Retrovirus and Associated Diseases in Marseille.

The physics prize goes to Herbert Walther, director of the Max Planck Institute for Quantum Optics, and Steven Chu, chairman of the department of physics at Stanford University, for their work in quantum optics. Walther invented the technique of trapping single photons in electromagnetic fields and Chu has developed new approaches to studying such systems.

David Dickson

\section{UK oceanographers ride the waves of uncertain funding}

London. Recent funding for British oceanographic science would mirror the topography of the subject - a series of peaks and troughs.

The good news is that the Natural Environment Research Council (NERC), which finances most of Britain's research on the oceans, has found the money for some badly needed equipment for its fleet of research vessels and that the University of Wales, Cardiff, has been picked to host the JOIDES planning office (see left). The bad news is that the NERC has been forced to curtail the number of research cruises planned for next year. In particular, the RRS Challenger will be laid up for one month in three so that only one crew is needed, and its sister ship, the RRS Darwin, is scheduled to be used two months for charter even though there are research projects that could have filled the slot.

Two factors have affected NERC's planning. The first has been the general squeeze on government funding for research. The second has been an unexpected increase in the cost of moving the research vessel service from its current base in Barry in South Wales to the Centre for Deep-Sea Oceanography in Southampton.

The resulting budgetary restrictions have meant a reduced investment in scientific equipment on the various research vessels, including the RRS Darwin, which was built in the mid-1980s, and the RRS Discovery, which has recently undergone a major conversion

Some of these concerns have now been assuaged. Last year's decision to purchase a swath bathymetry system was followed at the beginning of this month by an announcement that an extra $£ 400,000$ being made available through a reduced subscription to CERN (see Nature 361, 485; 1993) is to be used to buy a second TOBI (Towed Ocean Bottom Instrument) sidescan sonar package developed by the Institute of Oceanographic Sciences. In addition, the NERC is reported to be about to purchase for the Discovery two air compressors, essential equipment for profiling the ocean bed.

But there is still concern that cost reductions will prevent scientists from making full use of the research vessels. Further cuts in the Darwin's scientific cruises are threatened if the NERC fails to rent out the vessel in February and March 1994. And the opportunities for research on foreignowned vessels have been reduced by the NERC's reported decision to shelve a scheme under which such facilities have been made available in return for offering foreign researchers access to British cruises.

David Dickson 